\title{
Genetic diversity and differentiation in a southern beech subjected to introgressive hybridization
}

\author{
P. MARCHELLI*† \& L. A. GALLO \\ Unidad de Genética Forestal, Instituto Nacional de Tecnología Agropecuaria-EEA Bariloche, \\ CC 277, 8400 Bariloche, Argentina
}

\begin{abstract}
Diversity and differentiation among 11 Argentine populations of the South American southern beech, Nothofagus nervosa (Phil.) Dimitri \& Milano, were studied using eight isozyme gene markers. Genetic diversity, observed heterozygosity, mean number of alleles per locus, Gregorius' genetic distance, amount of genetic differentiation and mean level of differentiation among populations were estimated. Introgression of $N$. obliqua into the gene pool of $N$. nervosa was analysed using two species-specific isozyme gene markers $(A d h-A$ and $P g i-B)$. As in most forest tree species, the main genetic variation was found within populations. Mean observed heterozygosity for the species was $17.3 \%$, whilst mean level of genetic differentiation $\left(\delta_{\text {ge }}\right)$ was $4.6 \%$. The most differentiated locus was $M d h$ - $B$ with differences in $10 \%$ of the effective number of genes. From the analysis of the species distribution pattern it is suggested that genetic variation is geographically structured through the different lake watersheds along which the species is distributed. The occurrence of natural interspecific hybridization in some of the watersheds, together with the unidirectional gene flow along these watersheds sharpens this latitudinal structure. Different evolutionary stages in the introgressive hybridization process are apparently taking place in different lake watersheds.
\end{abstract}

Keywords: allozymes, Fagaceae, gene flow, geographical variation, Nothofagaceae, Nothofagus nervosa, population genetics.

\section{Introduction}

The amount and distribution of genetic variation among populations of a forest tree species is usually associated with ecological and geographical variation across its natural distribution. Genetic processes during the recent history of the species, such as genetic drift and gene flow, often contribute to current patterns of genetic variation. Nothofagus nervosa (Phil.) Dimitri \& Milano (Lennon et al., 1987) (=N. alpina), one of the most important forest tree species of the southern South American temperate forest, covers, in the Andes mountains of Argentina, a small distributional area (55 $000 \mathrm{ha}$ ) restricted to the valleys of the west-east glacial lake watersheds. Natural hybridization between $N$. nervosa and $N$. obliqua has been described based on morphological traits (Donoso et al., 1990; Gallo, 1995). The hybridization was confirmed using species-specific

*Correspondence. E-mail: pmarchelli@bariloche.inta.gov.ar $\nmid$ CONICET (Consejo Nacional de Investigaciones Científicas y Técnicas). isozyme markers, and $N$. nervosa was found to act mainly as the female and $N$. obliqua as the pollen donor (Gallo et al., 1997a,b). This introgression process may make an important contribution to the genetic variation of $N$. nervosa, perhaps greater than other factors.

The distribution pattern of $N$. nervosa and the westeast direction of strong winds, suggest that gene flow will be limited to within lake watersheds or the nearest connected ones. Thus, genetic variation may be associated with latitude and, particularly, with different lake watersheds. Chloroplast DNA markers showed a clear geographical variation between two groups of $N$. nervosa populations which were distributed south and north of a mountain chain (Marchelli et al., 1998).

Isozymic variation patterns related to geographical distribution have been described among the Fagaceae and the Nothofagaceae (Comps et al., 1990; MüllerStarck \& Ziehe, 1991; Haase, 1993; Zanetto \& Kremer, 1995; Premoli, 1997). In N. nervosa, isozymes were used to analyse Chilean populations (Carrasco \& Eaton, 1997), whereas genetic studies of the species in Argentina have dealt mainly with the determination of 
isozyme gene markers (Godoy, 1994; Marchelli \& Gallo, 2000). As in most other forest tree species, confirmed gene markers (i.e. through the genetic analysis of band segregation) have not been used to date for population genetic studies in $N$. nervosa. Additionally, isozyme genetic diversity and differentiation are usually estimated using Nei's $(1972,1973)$ and Wright's parameters (Wright, 1978), although strong arguments have been made against these (e.g. Gregorius \& Roberds, 1986).

In the present study, genetic variation among and within 11 populations of $N$. nervosa, distributed along its entire natural Argentinean range was analysed with Gregorius' parameters using eight isozyme gene markers. The distribution among different lake watersheds and the genetic variation supplied by the natural hybridization were especially taken into account.

\section{Materials and methods}

\section{Sampled populations}

Seeds from 11 populations of $N$. nervosa distributed over the entire natural Argentinean range were collected by placing nets below the canopy, $\approx 1.5 \mathrm{~m}$ above the ground (Fig. 1). Collections were made during the seedfall season (February-April) between 1994 and 1997. The nets were distributed within the stand (2-3 ha each) in order to capture seeds from a minimum of 40 trees in each population. Seeds were kept in plastic tubes at $4{ }^{\circ} \mathrm{C}$ until needed. A minimum of 100 seeds per population was analysed. Seeds of the 'full' mast year 1997 offers a better representation of all genotypes due to the high seed production (Marchelli \& Gallo, 1999), thus seeds from this year were used whenever possible (except populations 5, 10, 17 and 19).

\section{Electrophoretic analyses}

Protein extraction was performed from embryo tissue using Cheliak \& Pitel's (1984) vegetative extraction buffer I with slight modifications and electrophoresis was carried out on the day following protein extraction. Electrophoresis conditions, as well as gene marker determinations, are described in Marchelli \& Gallo (2000). Five enzyme systems encoding eight polymorphic loci were scored: $M d h-B, M d h-C, I d h-A, A d h-A$, Got-A, Got-B, Got-C and Pgi-B.

\section{Measurement of genetic variation}

Three among-population analyses were performed: (1) the first one corresponded to the 11 populations taken separately; (2) for a second analysis, populations were grouped according to the results of a previous chloroplast haplotype analysis (Marchelli et al., 1998); and (3) a third analysis was carried out comparing the populations grouped according to five geographically separated lake watersheds.

Genetic variation within populations was analysed as the mean number of alleles per locus $\left(A_{\mathrm{L}}\right)$, the percentage of polymorphic loci $(P)$, observed heterozygosity $\left(H_{\mathrm{o}}\right)$ and genetic diversity ( $v$; Gregorius, 1978), which corresponds to the effective number of alleles. $P$ refers to the total number of polymorphic loci found over all analysed populations. Differences in allele frequencies among populations were statistically tested by means of a Chi-squared goodness of fit test $(\alpha=0.05)$. Allelic genetic distance between populations was estimated using Gregorius' (1974) genetic distance, although for comparison purposes with other studies Nei's (1972) genetic distance was also calculated. Differences in the genetic distances were tested $(\alpha=0.05)$ using the program GDA_NT (Genetic Data Analysis and Numerical Tests) with 500 permutations (Degen, unpublished). The amount of genetic differentiation for a given population $(D j)$, measured as the distance of each population from its complement (remaining pooled populations), and the mean level of differentiation among populations $(\delta)$, were estimated for each locus according to Gregorius \& Roberds (1986). Population differentiation was measured both with allelic and genotypic data ( $\delta_{\text {ge }}$ and $\delta_{\text {go }}$, respectively); for comparison purposes, $F_{\mathrm{ST}}$ values (Wright, 1978) were also calculated. Dendrograms were constructed according to the UPGMA method using the SAS statistics program (SAS, 1989-96). Two computational programs were employed for the calculation of the different genetic parameters: GSED (Genetic Structures from Electrophoresis Data, Gillet, 1994) and POPGENe (Yeh \& Boyle, 1997).

\section{Results}

\section{Genetic diversity}

Three of the analysed loci were almost monomorphic ( $M d h-C, A d h-A$ and Pgi-B; Table 1). $M d h-C$ had one allele fixed in seven of the 11 populations, and the other allele was found only in the heterozygous condition. One allele was fixed at loci $A d h-A$ and $P g i-B$ in eight and seven populations, respectively. These two loci were found to have species-specific alleles, since one is fixed in $N$. nervosa and the other is fixed in $N$. obliqua, with hybrids between these two species having both alleles (Gallo et al., 1997a,b, 2000). Heterozygous seeds for both or only one of these loci were observed among the analysed populations. The 


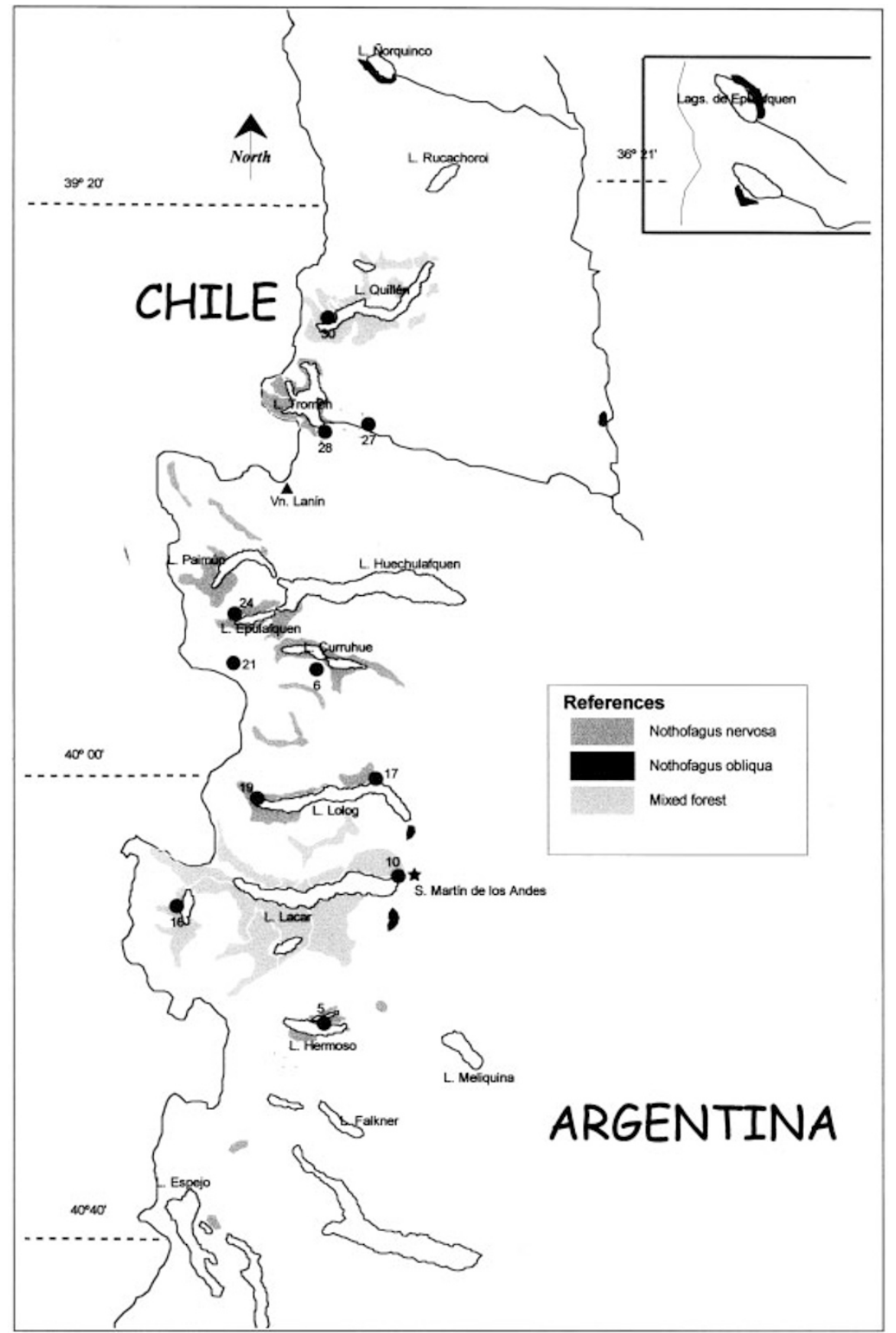

Fig. 1 Geographical location of the 11 Nothofagus nervosa populations analysed. Scale 1: 900000. frequency of hybrid seeds in population 10 from the Lacar Lake watershed was the greatest if both loci were involved $(3.5 \%$ for $A d h-A$ and $4.4 \%$ for Pgi-B; Table 1). Two seeds from 200 analysed from the Huechulafquen-Currhue watershed were heterozygous for Pgi-B (population 21), although $N$. obliqua does not occur at this site. These two seeds have the nervosa-type $A d h$ - $A$ pattern (homozygous for allele 2). Similarly, one seed of the 1207 analysed from popu- lation 27 (including the trees analysed for the genetic control) was heterozygous for $P g i-B$ and homozygous for $A d h-A$. In addition, heterozygous seeds for $A d h-A$ were found to be homozygous for Pgi-B (nervosa-type) in population 17 (Lolog Lake watershed) at a relatively high frequency $(16.7 \%)$. Among the other five analysed loci, $M d h-B$ was the most polymorphic. The mean observed heterozygosity for the species was $17.3 \%$.

(C) The Genetics Society of Great Britain, Heredity, 87, 284-293. 


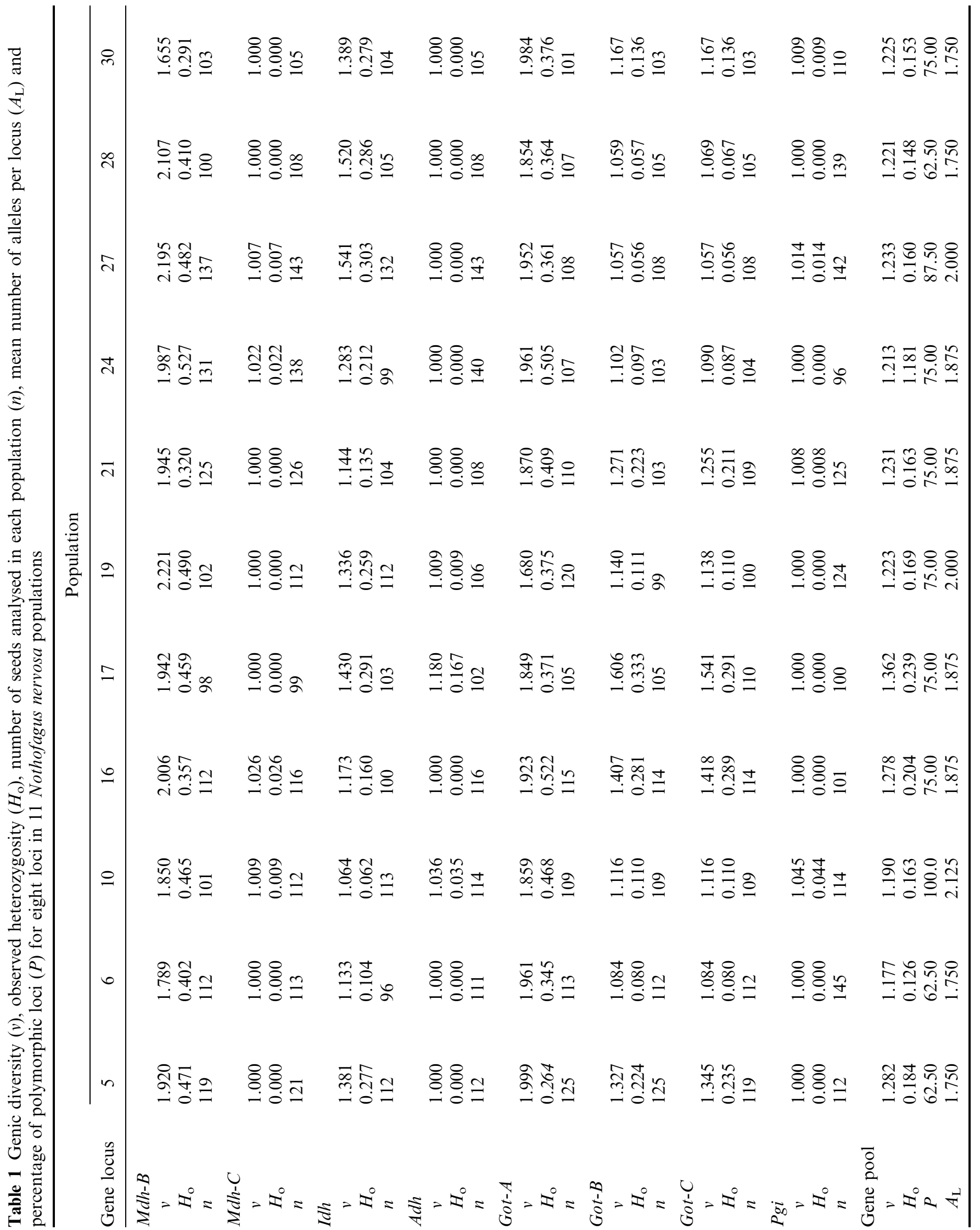

(c) The Genetics Society of Great Britain, Heredity, 87, 284-293. 
The mean number of alleles per locus $\left(A_{\mathrm{L}}\right)$ for all populations was 2.3 , whilst genic diversity ( $v$, effective number of alleles) ranged between 1.177 and 1.362 (Table 1).

\section{Genetic differentiation}

Table 2 shows Gregorius' and Nei's genetic distances for the gene pool and for $M d h-B$ (the locus with the highest genetic differentiation). Most pairwise Gregorius' genetic distances were significantly different $(\alpha=0.05)$ (Table 2). Gregorius' distances were much higher than Nei's distances (Table 2). One of the criticisms that Gregorius (1974) made of Nei's genetic distance is that in some cases the triangular inequality $\left(d_{(x, z)}+d_{(z, y)} \geq\right.$ $\left.d_{(x, y)}\right)$ does not hold. Several groups of populations were found where this condition was not fulfilled, e.g. populations 5, 6 and 10 and populations 6,28 and 30 (Table 2). The greatest genetic distances were observed between populations 17 and $30(0.113)$ and between populations 17 and 19 (0.093); the last two from the same lake watershed.

Differences among population differentiation were shown by the $D j$ values in the gene pool; population 17 was the most differentiated $(D j=0.073)$ and population 21 was the least differentiated $(D j=0.029$; Table 3$)$. The mean allelic differentiation $\left(\delta_{\text {ge }}\right)$ for the gene pool was 0.046 , with $M d h-B$ being the most differentiated locus $\left(\delta_{\mathrm{ge}}=0.099\right)$, indicating the mean proportion of effective numbers of genes by which populations differ from their complements (remaining populations) (Gregorius \& Roberds, 1986).

Similar values were obtained for $\delta_{\text {ge }}$ and $F_{\mathrm{ST}}$ in the gene pool although values for the different loci were highly variable. In general $\delta_{\text {ge }}$ was much greater than $F_{\mathrm{ST}}$, except for the almost monomorphic loci $(M d h-C$, $A d h-A$ and $P g i-B)$, where the latter was higher. Genetic differentiation at the genotypic level $\left(\delta_{\mathrm{go}}\right)$ was considerably greater than at the genic level; in some loci values for $\delta_{\mathrm{go}}$ were more than twice those obtained for $\delta_{\mathrm{ge}}$. Graphic representations of the $D j$ and $\delta$ values (the 'differentiation snails') proposed by Gregorius \& Roberds (1986) are shown in Fig. 2.

\section{Genetic variation among regions and watersheds}

The analysis of the allelic structure between the two groups of populations bearing different cpDNA haplotypes found by Marchelli et al. (1998), showed significant differences in allele frequencies at five of the eight analysed loci ( $M d h-B, I d h-A, A d h-A$, Got-B and Got-C; $\alpha=0.05$ ). All estimated genetic parameters were higher

Table 2 Genetic distances among the 11 Nothofagus nervosa populations for the locus with the higher differentiation $(M d h-B)$ (in the upper right diagonal half) and for the gene pool (in the lower diagonal half) according to Gregorius (1974). Nei's genetic distances (1972) are given in parentheses for comparison

\begin{tabular}{|c|c|c|c|c|c|c|c|c|c|c|c|}
\hline Population & 5 & 6 & 10 & 16 & 17 & 19 & 21 & 24 & 27 & 28 & 30 \\
\hline \multirow[t]{2}{*}{5} & - & 0.033 & 0.038 & 0.103 & 0.049 & $0.229 *$ & 0.082 & $0.141 *$ & $0.145^{*}$ & $0.147^{*}$ & $0.430^{*}$ \\
\hline & & $(0.001)$ & $(0.003)$ & $(0.017)$ & $(0.003)$ & $(0.103)$ & $(0.010)$ & $(0.031)$ & $(0.039)$ & $(0.039)$ & $(0.350)$ \\
\hline \multirow[t]{2}{*}{6} & $0.054 *$ & - & 0.033 & 0.103 & 0.055 & $0.257^{*}$ & 0.076 & $0.135^{*}$ & $0.172 *$ & $0.158^{*}$ & $0.425^{*}$ \\
\hline & $(0.005)$ & - & $(0.002)$ & $(0.018)$ & $(0.004)$ & $(0.110)$ & $(0.010)$ & $(0.031)$ & $(0.043)$ & $(0.041)$ & $(0.357)$ \\
\hline \multirow[t]{2}{*}{10} & $0.068^{*}$ & 0.026 & - & 0.073 & 0.026 & $0.227^{*}$ & 0.045 & 0.102 & $0.143^{*}$ & 0.128 & $0.392^{*}$ \\
\hline & $(0.008)$ & $(0.001)$ & - & $(0.008)$ & $(0.000)$ & $(0.081)$ & $(0.003)$ & $(0.017)$ & $(0.027)$ & $(0.025)$ & $(0.296)$ \\
\hline \multirow[t]{2}{*}{16} & $0.046^{*}$ & $0.055^{*}$ & $0.057^{*}$ & - & 0.055 & $0.154 *$ & 0.028 & 0.037 & 0.069 & 0.055 & $0.326^{*}$ \\
\hline & $(0.005)$ & $(0.007)$ & $(0.006)$ & - & $(0.006)$ & $(0.038)$ & $(0.001)$ & $(0.002)$ & $(0.006)$ & $(0.005)$ & $(0.198)$ \\
\hline \multirow[t]{2}{*}{17} & $0.061 *$ & $0.092 *$ & $0.081 *$ & $0.053^{*}$ & - & $0.201^{*}$ & 0.033 & 0.092 & $0.117^{*}$ & $0.103 *$ & $0.381 *$ \\
\hline & $(0.008)$ & $(0.015)$ & $(0.013)$ & $(0.005)$ & - & $(0.072)$ & $(0.002)$ & $(0.014)$ & $(0.022)$ & $(0.021)$ & $(0.279)$ \\
\hline \multirow[t]{2}{*}{19} & $0.081 *$ & $0.069^{*}$ & $0.061^{*}$ & $0.074 *$ & $0.093 *$ & - & $0.182 *$ & $0.131 *$ & 0.084 & 0.099 & $0.213^{*}$ \\
\hline & $(0.018)$ & $(0.013)$ & $(0.010)$ & $(0.010)$ & $(0.016)$ & - & $(0.053)$ & $(0.025)$ & $(0.014)$ & $(0.015)$ & $(0.063)$ \\
\hline \multirow[t]{2}{*}{21} & $0.048^{*}$ & $0.038^{*}$ & 0.032 & 0.026 & $0.062 *$ & $0.059^{*}$ & - & 0.059 & $0.097 *$ & 0.083 & $0.348^{*}$ \\
\hline & $(0.006)$ & $(0.003)$ & $(0.002)$ & $(0.001)$ & $(0.007)$ & $(0.007)$ & - & $(0.006)$ & $(0.012)$ & $(0.011)$ & $(0.232)$ \\
\hline \multirow[t]{2}{*}{24} & $0.059^{*}$ & 0.028 & $0.041^{*}$ & $0.047^{*}$ & $0.088^{*}$ & $0.045^{*}$ & $0.042 *$ & - & 0.047 & 0.032 & $0.289^{*}$ \\
\hline & $(0.007)$ & $(0.003)$ & $(0.004)$ & $(0.006)$ & $(0.014)$ & $(0.006)$ & $(0.003)$ & - & $(0.003)$ & $(0.001)$ & $(0.157)$ \\
\hline \multirow[t]{2}{*}{27} & $0.068 *$ & $0.048^{*}$ & $0.061 *$ & $0.069^{*}$ & $0.093 *$ & $0.050^{*}$ & $0.062 *$ & 0.025 & - & 0.021 & $0.290^{*}$ \\
\hline & $(0.009)$ & $(0.008)$ & $(0.009)$ & $(0.011)$ & $(0.018)$ & $(0.006)$ & $(0.008)$ & $(0.002)$ & - & $(0.001)$ & $(0.138)$ \\
\hline \multirow[t]{2}{*}{28} & $0.073^{*}$ & $0.050^{*}$ & $0.051 *$ & $0.068^{*}$ & $0.080^{*}$ & $0.041^{*}$ & $0.053^{*}$ & 0.029 & 0.013 & - & $0.283^{*}$ \\
\hline & $(0.011)$ & $(0.008)$ & $(0.008)$ & $(0.010)$ & $(0.016)$ & $(0.003)$ & $(0.007)$ & $(0.002)$ & $(0.001)$ & - & $(0.137)$ \\
\hline \multirow[t]{2}{*}{30} & $0.079 *$ & $0.080^{*}$ & $0.088^{*}$ & $0.086^{*}$ & $0.113^{*}$ & $0.056^{*}$ & $0.077 *$ & $0.054 *$ & $0.061 *$ & $0.066^{*}$ & - \\
\hline & $(0.028)$ & $(0.029)$ & $(0.027)$ & $(0.021)$ & $(0.032)$ & $(0.011)$ & $(0.021)$ & $(0.013)$ & $(0.013)$ & $(0.014)$ & - \\
\hline
\end{tabular}

* Significant at the 0.05 level. 
Table 3 Genetic differentiation ( $D j$ and $\delta$ ) at the genic and genotypic (in parentheses) level in 11 populations of Nothofagus nervosa. Wright's $F_{\mathrm{ST}}$ values are given for comparison

\begin{tabular}{|c|c|c|c|c|c|c|c|c|c|c|c|c|c|}
\hline \multirow[b]{2}{*}{ Locus } & \multicolumn{13}{|c|}{ Population } \\
\hline & 5 & 6 & 10 & 16 & 17 & 19 & 21 & 24 & 27 & 28 & 30 & $\delta$ & $F_{\mathrm{ST}}$ \\
\hline$A d h$ & $\begin{array}{c}0.133 \\
0138\end{array}$ & $\begin{array}{c}0.139 \\
0149\end{array}$ & 0.106 & $\begin{array}{c}0.026 \\
0.076\end{array}$ & $\begin{array}{c}0.078 \\
0.099\end{array}$ & $\begin{array}{c}0.142 \\
(0159)\end{array}$ & & $\begin{array}{c}0.023 \\
(0159)\end{array}$ & $\begin{array}{c}0.051 \\
(0.078)\end{array}$ & $\begin{array}{c}0.034 \\
0.067)\end{array}$ & $\begin{array}{c}0.337 \\
0388)\end{array}$ & $\begin{array}{c}0.099 \\
0143)\end{array}$ & 0.052 \\
\hline$M d h-C$ & $\begin{array}{c}0.003 \\
(0.007)\end{array}$ & $\begin{array}{c}0.003 \\
(0.007)\end{array}$ & $\begin{array}{c}0.002 \\
(0.003)\end{array}$ & $\begin{array}{c}0.011 \\
(0.022)\end{array}$ & $\begin{array}{c}0.003 \\
(0.007)\end{array}$ & $\begin{array}{c}0.003 \\
(0.007)\end{array}$ & $\begin{array}{c}0.003 \\
(0.007)\end{array}$ & $\begin{array}{c}0.009 \\
(0.017)\end{array}$ & $\begin{array}{c}0.000 \\
(0.001)\end{array}$ & $\begin{array}{c}0.003 \\
(0.007)\end{array}$ & $\begin{array}{c}0.003 \\
(0.007)\end{array}$ & $\begin{array}{c}0.004 \\
(0.008)\end{array}$ & 0.007 \\
\hline$I d h$ & $\begin{array}{c}0.031 \\
(0.065)\end{array}$ & $\begin{array}{c}0.081 \\
(0.143)\end{array}$ & $\begin{array}{c}0.117 \\
(0.203)\end{array}$ & $\begin{array}{c}0.062 \\
(0.094)\end{array}$ & $\begin{array}{c}0.052 \\
(0.092)\end{array}$ & $\begin{array}{c}0.012 \\
(0.045)\end{array}$ & $\begin{array}{c}0.076 \\
(0.122)\end{array}$ & $\begin{array}{c}0.012 \\
(0.015)\end{array}$ & $\begin{array}{c}0.102 \\
(0.150)\end{array}$ & $\begin{array}{c}0.090 \\
(0.127)\end{array}$ & $\begin{array}{c}0.034 \\
(0.068)\end{array}$ & $\begin{array}{c}0.062 \\
(0.104)\end{array}$ & 0.034 \\
\hline$A d h$ & $\begin{array}{c}0.010 \\
(0.019)\end{array}$ & $\begin{array}{c}0.010 \\
(0.019)\end{array}$ & $\begin{array}{c}0.010 \\
(0.019)\end{array}$ & $\begin{array}{c}0.010 \\
(0.019)\end{array}$ & $\begin{array}{c}0.081 \\
(0.162)\end{array}$ & $\begin{array}{c}0.004 \\
(0.009)\end{array}$ & $\begin{array}{c}0.010 \\
(0.019)\end{array}$ & $\begin{array}{c}0.010 \\
(0.020)\end{array}$ & $\begin{array}{c}0.010 \\
(0.020)\end{array}$ & $\begin{array}{c}0.010 \\
(0.019)\end{array}$ & $\begin{array}{c}0.009 \\
(0.019)\end{array}$ & $\begin{array}{c}0.015 \\
(0.030)\end{array}$ & 0.060 \\
\hline fot $-A$ & $\begin{array}{c}0.124 \\
(0.196)\end{array}$ & $\begin{array}{c}0.035 \\
(0.062)\end{array}$ & $\begin{array}{c}0.039 \\
(0.081)\end{array}$ & $\begin{array}{c}0.003 \\
(0.141)\end{array}$ & $\begin{array}{c}0.044 \\
(0.057)\end{array}$ & $\begin{array}{c}0.135 \\
(0.151)\end{array}$ & $\begin{array}{c}0.032 \\
(0.041)\end{array}$ & $\begin{array}{c}0.036 \\
(0.121)\end{array}$ & $\begin{array}{c}0.027 \\
(0.045)\end{array}$ & $\begin{array}{c}0.041 \\
(0.058)\end{array}$ & $\begin{array}{c}0.064 \\
(0.073)\end{array}$ & $\begin{array}{c}0.054 \\
(0.096)\end{array}$ & 0.014 \\
\hline Got- $B$ & $\begin{array}{c}0.054 \\
(0.092)\end{array}$ & $\begin{array}{c}0.061 \\
(0.103)\end{array}$ & $\begin{array}{c}0.044 \\
(0.070)\end{array}$ & $\begin{array}{c}0.089 \\
(0.157)\end{array}$ & $\begin{array}{c}0.172 \\
(0.269)\end{array}$ & $\begin{array}{c}0.032 \\
(0.057)\end{array}$ & $\begin{array}{c}0.029 \\
(0.073)\end{array}$ & $\begin{array}{c}0.051 \\
(0.084)\end{array}$ & $\begin{array}{c}0.074 \\
(0.130)\end{array}$ & $\begin{array}{c}0.073 \\
(0.128)\end{array}$ & $\begin{array}{c}0.019 \\
(0.031)\end{array}$ & $\begin{array}{c}0.064 \\
(0.109)\end{array}$ & 0.055 \\
\hline Got-C & $\begin{array}{c}0.064 \\
(0.109)\end{array}$ & $\begin{array}{c}0.059 \\
(0.100)\end{array}$ & $\begin{array}{c}0.043 \\
(0.067)\end{array}$ & $\begin{array}{c}0.095 \\
(0.170)\end{array}$ & $\begin{array}{c}0.147 \\
(0.222)\end{array}$ & $\begin{array}{c}0.032 \\
(0.056)\end{array}$ & $\begin{array}{c}0.023 \\
(0.062)\end{array}$ & $\begin{array}{c}0.055 \\
(0.093)\end{array}$ & $\begin{array}{c}0.073 \\
(0.127)\end{array}$ & $\begin{array}{c}0.066 \\
(0.114)\end{array}$ & $\begin{array}{c}0.018 \\
(0.028)\end{array}$ & $\begin{array}{c}0.062 \\
(0.105)\end{array}$ & 0.049 \\
\hline Dgi & $\begin{array}{c}0.004 \\
(0.008)\end{array}$ & $\begin{array}{c}0.004 \\
(0.009)\end{array}$ & $\begin{array}{c}0.020 \\
(0.040)\end{array}$ & $\begin{array}{c}0.004 \\
(0.008)\end{array}$ & $\begin{array}{c}0.004 \\
(0.008)\end{array}$ & $\begin{array}{c}0.004 \\
(0.008)\end{array}$ & $\begin{array}{l}0.000 \\
0.000\end{array}$ & $\begin{array}{c}0.004 \\
(0.007)\end{array}$ & $\begin{array}{c}0.004 \\
(0.007)\end{array}$ & $\begin{array}{c}0.004 \\
(0.009)\end{array}$ & $\begin{array}{c}0.001 \\
(0.002)\end{array}$ & $\begin{array}{c}0.005 \\
(0.009)\end{array}$ & 010 \\
\hline $\begin{array}{l}\text { Gene } \\
\text { pool }\end{array}$ & $\begin{array}{c}0.053 \\
(0.079)\end{array}$ & $\begin{array}{c}0.049 \\
(0.074)\end{array}$ & $\begin{array}{c}0.047 \\
(0.081)\end{array}$ & $\begin{array}{c}0.037 \\
(0.086)\end{array}$ & $\begin{array}{c}0.073 \\
(0.115)\end{array}$ & $\begin{array}{c}0.046 \\
(0.062)\end{array}$ & $\begin{array}{c}0.029 \\
(0.055)\end{array}$ & $\begin{array}{c}0.025 \\
(0.065)\end{array}$ & $\begin{array}{c}0.043 \\
(0.070)\end{array}$ & $\begin{array}{c}0.040 \\
(0.066)\end{array}$ & $\begin{array}{c}0.061 \\
(0.077)\end{array}$ & $\begin{array}{c}0.046 \\
(0.076)\end{array}$ & 0.038 \\
\hline
\end{tabular}

in the southern compared to the northern region (Table 4).

Depending on the watershed analysed, homogeneity in allele frequencies between populations within watersheds was found for three (Lacar), four (Lolog and Huechulafquen) or five (Tromen-Quillén) loci. Only $M d h-C$ and Got- $A$ were homogeneous between populations in all watersheds. Moreover, population differentiation within watersheds $\left(\delta_{\text {ge }}\right)$ was high in some cases (e.g. Lolog Lake watershed; Table 4). In spite of this partial heterogeneity, populations within watersheds were pooled for all loci in order to analyse the latitudinal variation. Significant differences in the allelic structure of all but one locus $(M d h-C)$ were found among watersheds $(\alpha=0.05)$. Genetic distances between all pairs of watersheds were also significantly different. The northernmost watershed (Tromen-Quillén) was completely separated from the rest according to the gene pool genetic distance, coinciding with cpDNA haplotypes (Fig. 3).

\section{Discussion}

Most of the genetic variation observed in N. nervosa was found within, rather than among populations. Mean observed heterozygosity for the species was $17.3 \%$, which is slightly lower than values observed in other Fagaceae (e.g. Müller-Starck \& Ziehe, 1991; Zanetto \& Kremer, 1995). On the other hand, observed heterozygosity in $N$. nervosa is much higher than values obtained in other South American Nothofagus species [e.g. $N$. dombeyi $(8.2 \%), N$. betuloides $(9.8 \%)$ and $N$. nitida (3.6\%) (Premoli, 1997)]. The same holds for values observed in New Zealand Nothofagus where they ranged from 2.5 to $10.5 \%$ in five species (Haase, 1993). However, it should be noted that in the last two works, both monomorphic and polymorphic loci were included in the analysis, most of which were monomorphic. In this study, monomorphic loci were excluded since they could not be recognized as gene markers in the segregation analysis (Marchelli \& Gallo, 2000); only polymorphic loci allow genetic analysis and therefore the identification of gene markers.

As regards the other measures of intrapopulation variation, genic diversity $(v)$ for the gene pool ranged between 1.177 and 1.362. These values are slightly lower than values observed in Quercus robur and Q. petraea $(v=1.4$ in both species; Müller-Starck et al., 1993) and in Fagus sylvatica ( $v=1.55$; Gregorius et al., 1986). Relatively small genetic diversities denote minor polymorphisms with one allele at high frequency and a few rare alleles (Müller-Starck et al., 1993). The mean number of alleles per locus was 2.25; a value that is similar to those obtained in other species (Müller-Starck et al., 1992). The difference between $A_{\mathrm{L}}$ and $v$ accounts for the presence of alleles at low frequencies.

In most of the literature, Wright's $F_{\mathrm{ST}}$ (or Nei's $G_{\mathrm{ST}}$ ) is used as a measure of genetic differentiation. However, Gregorius \& Roberds (1986) have highlighted some conceptual weaknesses of this measure; $F_{\mathrm{ST}}$ equals 1 
(a)

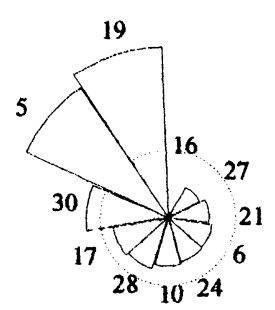

GOT-A

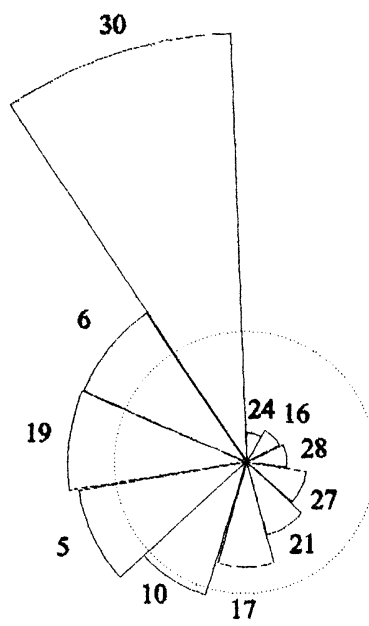

MDH-B

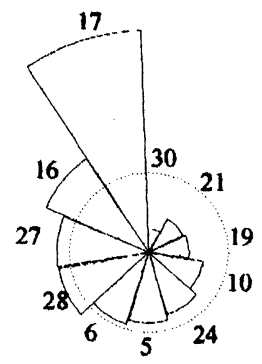

GOT-B

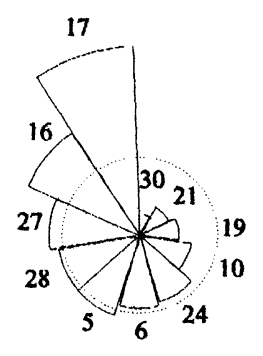

\section{GOT-C}

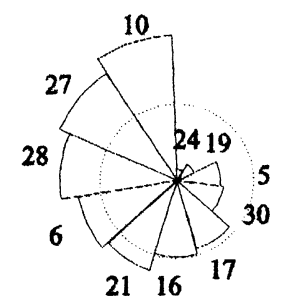

IDH

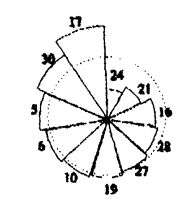

(b)

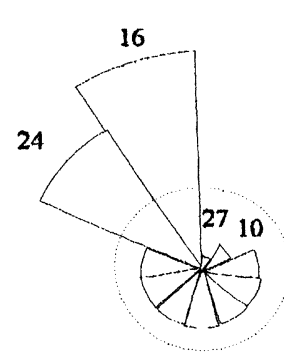

MDH-C

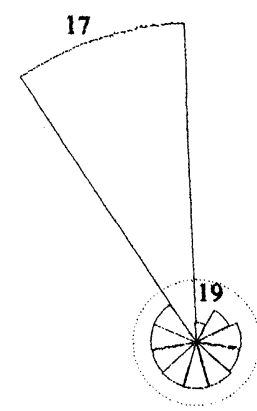

$\mathrm{ADH}$

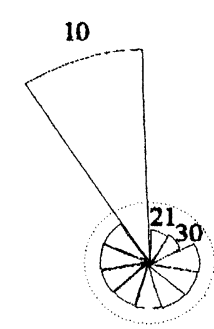

PGI
Fig. 2 "Differentiation snails" (according to Gregorius \& Roberds, 1986). (a) Genetic differentiation among populations of Nothofagus nervosa for the five analysed loci and the gene pool. The radius of the dotted circle in each graph represents the average level of allelic differentiation $(\delta)$ for that particular locus. Each triangle represents a population, the radius indicates the level of genetic differentiation $(D j)$ and the angle denotes sample size. (b) Amplification of the graphs for the three less differentiated loci ( $M d h-C$ : 17 times; $A d h: 3$ times and Pgi: 9 times). only if all populations are genetically fixed, including fixation for the same allele, which contradicts the concept of complete differentiation. In this sense, our data show that $F_{\mathrm{ST}}$ reaches the highest value for $A d h-A$ $\left(F_{\mathrm{ST}}=6 \%\right.$, Table 3$)$, which is fixed for the same allele in eight out of the 11 populations (Table 1), thus supporting our choice of the mean level of differentiation among populations ( $\delta$; Gregorius \& Roberds, 1986) as an estimator of genetic differentiation.
Little population differentiation was observed among the 11 populations studied $\left(\delta_{\mathrm{ge}}=4.6 \% ; F_{\mathrm{ST}}=3.8 \%\right)$, coinciding with the values of $\delta_{\text {ge }}$ obtained in Fagus sylvatica and Quercus robur (4.5 and 5.5\%, respectively) but lower than that observed in $Q$. petraea $(8.5 \%$; Müller-Starck \& Ziehe, 1991). However, this differentiation value could be considered as relatively high, given the very small natural distribution area of $N$. nervosa analysed in this study. The most differentiated 
Table 4 Genetic variation in Nothofagus nervosa in two regions separated by chloroplast DNA (Marchelli et al., 1998) and five different watersheds: 1 (Hermoso Lake); 2 (Lacar Lake); 3 (Lolog Lake) 4 (Huechulafquen-Currhue Lakes); 5 (Tromen-Quillén Lakes). $F_{\mathrm{ST}}$ values are given in parentheses

\begin{tabular}{|c|c|c|c|c|c|c|c|}
\hline & \multicolumn{2}{|c|}{ Cp DNA haplotypes } & \multicolumn{5}{|c|}{ Watersheds } \\
\hline & $\begin{array}{l}\text { Northern } \\
\text { region }\end{array}$ & $\begin{array}{l}\text { Southern } \\
\text { region }\end{array}$ & 1 & 2 & 3 & 4 & 5 \\
\hline $\mathrm{P}(\%)$ & 87.5 & 100 & 62.5 & 100 & 75 & 87.5 & 87.5 \\
\hline$A_{\mathrm{L}}$ & 2.00 & 2.25 & 1.75 & 2.125 & 2.00 & 2.00 & 2.00 \\
\hline$v$ & 1.234 & 1.251 & 1.282 & 1.237 & 1.301 & 1.209 & 1.234 \\
\hline$H_{\mathrm{o}}$ & 0.155 & 0.179 & 0.184 & 0.184 & 0.205 & 0.157 & 0.155 \\
\hline$D j$ & 0.053 & 0.053 & 0.053 & 0.033 & 0.047 & 0.032 & 0.053 \\
\hline$\delta_{\mathrm{ge}}$ & $0.043(0.026)$ & $0.044(0.028)$ & $\dagger$ & $0.057(0.013)$ & $0.093(0.030)$ & $0.033(0.010)$ & $0.043(0.026)$ \\
\hline
\end{tabular}

$\dagger$ Single population.
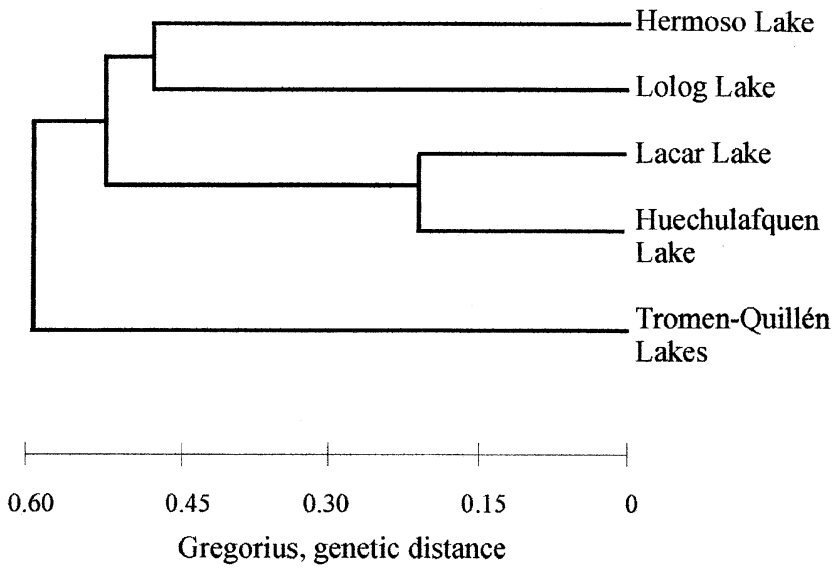

Fig. 3 Clustering of the five lake watersheds according to the UPGMA method using Gregorius' genetic distances.

locus was $M d h-B$ with differences in almost $10 \%$ of the effective number of genes by which populations differ from their complements. The general mean was low due to the low differentiation of $M d h-C$ and the two speciesspecific loci ( $A d h-A$ and Pgi-B). Differences in the mean level of differentiation were observed when comparing genic and genotypic data. Values for mean genotypic differentiation $\left(\delta_{\mathrm{go}}\right)$ were almost twice those found for mean genic differentiation $\left(\delta_{\text {ge }}\right)$, indicating that organization of gametes into genotypes implies a higher differentiation. Gregorius \& Roberds (1986) obtained similar results in Pinus ponderosa $\left(\delta_{\mathrm{ge}}=0.061\right.$ and $\left.\delta_{\mathrm{go}}=0.113\right)$.

The results are in agreement with the distribution of the genetic variation observed in forest tree species, since most $F_{\mathrm{ST}}$ values were less than 0.100 , indicating low genetic differentiation between populations (Comps et al., 1991). Great intrapopulation variation and little population differentiation were observed in beech and oaks (Müller-Starck \& Ziehe, 1991), and in South
American and New Zealand Nothofagus species (Haase, 1993; Premoli, 1997).

Even though genetic distances among watersheds were rather small (between 0.023 and 0.072), they were significantly different $(\alpha=0.05)$ (Fig. 3). Clustering of the watersheds in the dendrogram showed a greater similarity between Lacar and Huechulafquen-Currhue watersheds than between either of these and the Lolog watershed, which is geographically situated between them (Fig. 1). Analysing the whole distribution, a latitudinal separation can be seen, especially between the northernmost watershed and those situated in the south, since the Tromen-Quillén watershed was clearly separated from the rest (Fig. 3). The highest genetic distance was found between this watershed and the southernmost. This agrees with results obtained with chloroplast DNA markers and supports the idea that there were at least two refugia for $N$. nervosa during the last glaciation (Marchelli et al., 1998). It could be suggested that the main wind direction during pollination time along the valleys of the watersheds could geographically structure the genetic variation in gene flow corridors along the different lake watersheds. According to the cpDNA results, population 30 (from Quillén Lake) was grouped with populations 27 and 28 (from Tromen Lake). However, in the present allozyme analysis, it showed a higher differentiation level than them, suggesting that probably the Quillén watershed could belong to a different gene flow corridor.

Curiously, some populations belonging to the same watershed were genetically very different, e.g. populations 17 and 19 from the Lolog watershed $(d=0.093)$, whilst others were relatively similar (populations 27 and 28 from Tromen Lake, $d=0.013$ ) (Fig. 2). Homogeneity in allele frequencies among populations within watersheds could only be found at some of the loci, showing the occurrence of differences within watersheds. The differentiation among populations within the Lolog 
watershed suggests the possibility of another refugium, perhaps to the east, from which population 17 could have originated. Analyses of more populations within watersheds would allow a better understanding of patterns of genetic variation in $N$. nervosa.

It is worth noting that the hybridization between $N$. nervosa and $N$. obliqua introduces an important source of genetic variation. When the two speciesspecific loci ( $A d h-A$ and $P g i-B)$, fixed in many populations, are not considered, all estimated parameters were increased $\left(H_{\mathrm{o}}=23 \% ; v\right.$ ranged between 1.25 and 1.49 ; $\left.\delta_{\mathrm{ge}}=5.7 \%\right)$. On the other hand, if only these loci $(A d h-A$ and $P g i-B)$ are considered, which means the variation inherent to $N$. obliqua, clustering could be different due to the presence of hybrids in populations from the Lacar and Lolog watersheds. If this is done, the Lacar and Lolog watersheds are clearly distinct from the rest (data not shown). The high proportion of hybrid seeds for $A d h-A$ in population 17 is the main contribution for the great distance observed between this population and population 19, and accounts for the high level of differentiation observed between these two populations $(\delta=0.093)$. The low frequency of hybrids in population 19 (only one seed among 106 analysed for $A d h-A$ ), is strongly related to the distribution of $N$. obliqua, since pollen could reach population 17 from a small mixed population situated on the other margin of the lake. Gene flow from population 17 to 19 is restricted due to a main west-east wind direction. It is important to point out here that the analysed seeds were collected during the same season, since it is known that frequency of hybridization not only varies in space, but also in time (Gallo et al., 1997b).

Among the analysed populations, the occurrence of hybrid seeds for one of the species-specific loci, but not for the other, was observed, indicating the independence of these two loci and, furthermore, suggesting the presence of adult hybrids that must be fertile. It is worth noting that these hybrid seeds, heterozygous for one locus, showed $N$. nervosa homozygous type for the other one. The high proportion of hybrid seeds observed for $A d h-A$ in the Lolog watershed (population 17) together with the lack of hybrids for Pgi-B, contrasts with the frequency of hybridization observed in the Lacar lake watershed, where both species are in sympatry. This could indicate, among others, a different evolutionary stage in the hybridization (or introgression) process in each watershed. The Lolog lake watershed could be in a more advanced evolutionary stage than the Lacar lake watershed, since a great proportion of backcrosses should be assumed. The proportion of hybrid adult trees in natural populations is low compared to that observed among offspring of individual trees in progeny tests. Post-zygotic incompa- tibility is probably taking place through a diminished adaptive capacity of the hybrids. This selection helps to maintain the separation of the two species' gene pools, at least to a certain degree (Gallo et al., 2000). It would be of great interest to conduct an exhaustive study of Lolog watershed to investigate gene flow distances and hybridization frequencies.

It should be emphasized that introgressive hybridization clearly sharpens the latitudinal differentiation caused by the unidirectional gene flow that takes place along each watershed. The different capacity of both species to overcome high altitude passes during the postglaciation colonization (due to their different thermal responses) has probably affected their current distribution along the different lake watersheds. There are watersheds with both species in sympatry (e.g. Lacar, Quillén) and others with the occurrence of only 'pure' (at least phenotypically) species (e.g. Hermoso, Lolog, Huechulafquen). Nevertheless, in the latter group, pollination with $N$. obliqua pollen coming from populations on the other side of the Andes Mountains cannot be excluded. If this is possible the concept of the genetic population could be extended to a larger regional level and therefore the 'sympatry area' of both species should be also increased. Hybrids between $N$. nervosa and $N$. obliqua should be taken into account in conservation and management of natural populations, especially of the former species, since it introduces another component into its genetic variation. Silvicultural management of the one-to-one mixed forest could affect the proportion of hybrid seeds, increasing the number of not so well adapted hybrid individuals with detrimental consequences for natural regeneration.

\section{Acknowledgements}

The authors would like to thanks Forest Technician Fernanda Izquierdo and Dr J. Esteban Gayone for helping with the figures, and two anonymous reviewers for critical and helpful comments on the manuscript. This work was partially supported by a common project between National Parks Administration (APN) and National Institute of Agricultural Technology (INTA) and by a grant from the IFS (International Foundation for Science) $\mathrm{D} / 2458-1$.

\section{References}

CARRASCO, B. AND EATON, L. 1997. Genetic considerations for the conservation of Raulí (Nothofagus alpina (Poepp. et Endl., Oerst.). II Southern Connection Congress. 6-11 January 1997, Valdivia, Chile, pp. 139-140.

CHELIAK, W. M. AND PITEL, J. A. 1984. Techniques for starch gel electrophoresis of enzymes from forest tree species. 
Information Report PI-X-42. Petawawa National Forestry Institute. Canadian Forestry Service, Agriculture Canada. COMPS, B., ThiÉBAut, B., PAUle, L., MERZEAU, D. ET AL. 1990. Allozymic variability in beechwoods (Fagus sylvatica L.) over central Europe: spatial differentiation among and within populations. Heredity, 65, 407-417.

COMPS, B., THIéBAUT, B. AND MERZEAU, D. 1991. Genetic variation in European beech stands (Fagus sylvatica L.). In: Müller-Starck, G. and Ziehe, M. (eds). Genetic Variation in European Populations of Forest Trees, pp. 110-124. Sauerländer's Verlag, Frankfurt am Main.

DONOSO, C., MORALES, J. AND ROMERO, M. 1990. Hibridación natural entre roble (Nothofagus obliqua (Mirb.) Oerst.) y raulí ( $N$. alpina (Poepp. and Endl.) Oerst.) en bosques del sur de Chile. Revista Chilena Historia Natural, 63, 49-60.

GAllo, L. A. 1995. Supuestos híbridos interespecíficos en progenies de Raulí. XXVI Congreso Argentino de Genética. 23-25 October, 1995, Bariloche, Argentina, 34 pp.

GALlO, L. A., MARCHELli, P. AND BREITEMBÜCHER, A. 1997a. Allozymic heterozygosity in families with natural hybrids between two southern beeches (Nothofagus spp.). II Southern Connection Congress, 6-11 January 1997, Valdivia, Chile, 152 pp.

GALlO, L. A., MARCHELli, P. AND BREITEMBÜCHER, A. $1997 \mathrm{~b}$. Morphological and allozymic evidence of natural hybridisation between two southern beeches (Nothofagus spp.) and its relation to heterozygosity and height growth. Forest Genet., 4, 15-23.

GALlO, L. A., MARCHELli, P. AND CREGO, P. 2000. Hybridisation dynamic between two southern beeches (Nothofagus spp.). XXI IUFRO World Congress, 7-12 August 2000, Kuala Lumpur, Malaysia, 2, 43-44.

GILLET, E. 1994. Genetic structures from electrophoresis data, version 1.0. Abteilung für Forstgenetik und Forstpflanzenzüchtung, Universität Göttingen, Göttingen.

Godoy, M. 1994. Determinación de isoenzimas y análisis genéticos en Nothofagus nervosa (Phil) Dim. et Mil. (rauli). Trabajo científico para la obtención del grado 'Magister der tropischen Forstwirtschaft' en el área de Ciencias Forestales de la Universidad Georg-August de Göttingen, Alemania.

GREGORIUS, H. R. 1974. On the concept of genetic distance between populations based on gene frequencies. In: Proc. Joint IUFRO Meeting, S.02.04.1-3, Stockholm, Session I, pp. 17-26.

GREGORIUS, H. R. 1978. The concept of genetic diversity and its formal relationship to heterozygosity and genetic distance. Math. Biosci., 41, 253-271.

GREGORIUS, H. R. AND ROBERDS, J. H. 1986. Measurement of genetical differentiation among subpopulations. Theor. Appl. Genet., 71, 826-834.

GREGORIUS, H. R., KRAUHAUSEN, J. AND MÜLLER-STARCK, G. 1986. Spatial and temporal genetic differentiation among the seed in a stand of Fagus sylvatica L. Heredity, 57, 255-262.

HAASE, P. 1993. Isozyme studies of New Zealand Nothofagus species (Southern beech) using leaf extracts. Silvae Genetica, 42, 46-51.

LENNON, J. A., MARTin, E. S., STEVEN, R. A. AND WigSton, D. L. 1987. Nothofagus nervosa (Phil.) Dim. et Mil. - The correct name for raulí, Chilean southern beech, (N. procera). Arboricultural J., 11, 323-332.

MARChElli, P. AND GAllo, L. A. 1999. Annual and geographic variation in seed traits of Argentinean populations of southern beech Nothofagus nervosa (Phil.) Dim. et Mil. For. Ecol. Management, 121, 239-250.

MARCHELli, P. AND GALlo, L. A. 2000. Genetic analysis of isozyme variants in open pollinated families of Southern beech Nothofagus nervosa (Phil.) Dim. et Mil. Silvae Genetica, 49, 90-98.

MARCHELLI, P., GALlO, L. A., SCHOLZ, F. AND ZIEGENHAGEN, B. 1998. Chloroplast DNA markers revealed a geographical divide across Argentinean southern beech Nothofagus nervosa (Phil.) Dim. et Mil. distribution area. Theor. Appl. Genet., 97, 642-646.

MÜLLER-STARCK, G. AND ZIEHE, M. 1991. Genetic variation in populations of Fagus sylvatica L., Quercus robur L. and Q. petraea (Matt.) Liebl. in Germany. In: Müller-Starck, G. and Ziehe, M. (eds) Genetic Variation in European Populations of Forest Trees, pp. 125-140. Sauerländer's Verlag, Frankfurt am Main.

MÜLLER-STARCK, G., BARADAT, PH. AND BERGMANN, F. 1992. Genetic variation in European tree species. New Forests, 6, 23-47.

MÜLLER-STARCK, G., HERZOG, S. AND HATTEMER, H. H. 1993. Intra- and interpopulational genetic variation in juvenile populations of Quercus robur L. and Quercus petraea (Matt.) Liebl. Ann. Sci. For., 50, 233s-244s.

NEI, M. 1972. Genetic distance between populations. Am. Nat., 106, 283-292.

NEI, M. 1973. Analysis of gene diversity in subdivided populations. Proc. Natl. Acad. Sci. U.S.A., 70, 3321-3323.

PREMOLI, A. C. 1997. Genetic variation in a geographically restricted and two widespread species of South American Nothofagus. J. Biogeogr., 24, 883-892.

SAS INSTITUTE. 1989-96. SAS (Language guide for personal computers, release 6.12. Cary, NC 27513, USA.

Wright, s. 1978. Evolution and the Genetics of Populations, vol. 4 Variability Within and Among Natural Populations. The University of Chicago Press, Chicago.

YEH, F. C. AND BOYLE, T. 1997. POPGENE, version 1.2 Microsoft Windows-based Software for Population Genetics Analysis. University of Alberta and Center for International Terestry Research, Alberta, Canada.

ZANETTO, A. AND KREMER, A. 1995. Geographical structure of gene diversity in Quercus petraea (Matt.) Liebl. I. Monolocus patterns of variation. Heredity, 75, 506-517. 